Original Research Paper

\title{
Characterization of Activated Carbon from Eggshell Membranes Prepared Using Sodium Acetate and Zinc Metal Activation
}

\author{
Sumrit Mopoung and Kanjana Jitchaijaroenkul \\ Department of Chemistry, Faculty of Science, Naresuan University, Phitsanulok 65000, Thailand
}

\author{
Article history \\ Received: 14-06-2017 \\ Revised: $10-07-2017$ \\ Accepted: 31-07-2017 \\ Corresponding Author: \\ Sumrit Mopoung \\ Department of Chemistry, \\ Faculty of Science, Naresuan \\ University, Phitsanulok 65000, \\ Thailand \\ Email: sumrotm@nu.ac.th
}

\begin{abstract}
The eggshell membranes of ducks and hens were carbonized or activated with $4 \mathrm{wt} \%$ sodium acetate or zinc at $400-600^{\circ} \mathrm{C}$. The carbonized or activated products were characterized by SEM-EDS, TEM, FTIR and $\mathrm{XRD}$. It was found that the suitable activation temperature for eggshell membranes is $500^{\circ} \mathrm{C}$ with $30.03-35.26 \%$ yield. The activation performance of $\mathrm{CH}_{3} \mathrm{COONa}$ for eggshell membrane activated carbon production was higher than that of $\mathrm{Zn}$ metal. The $\mathrm{CO}_{3}{ }^{2-}, \mathrm{Ca}-\mathrm{O}, \mathrm{C}=\mathrm{C}$, Na-O and $\mathrm{C}-\mathrm{O}$ functional groups have been formed on the surface of eggshell membrane activated carbon materials during both $\mathrm{CH}_{3} \mathrm{COONa}$ and $\mathrm{Zn}$ activation. Furthermore, $\mathrm{CaO}, \mathrm{MgO}, \mathrm{Na}_{2} \mathrm{O}$ and $\mathrm{ZnO}$ have also accumulated on eggshell membrane activated carbon materials with high content and regular dispersion. It was shown that the particles on the duck eggshell membrane activated carbon formed with $\mathrm{Zn}$ had weaker attachment on the surface than for duck eggshell membrane activated carbon formed with $\mathrm{CH}_{3} \mathrm{COONa}$ at same temperature. The XRD and TEM results revealed that the eggshell membrane activated carbons consist of an amorphous carbon matrix with some disordered graphite carbon matrix, spherical particles and nanofiber.
\end{abstract}

Keywords: Eggshell Membrane, Activated Carbon, Sodium Acetate, Zinc

\section{Introduction}

Large quantities of egg waste are discarded worldwide. They consist of egg shells and Eggshell Membranes (ESM) (Mittal et al., 2016). The ESM resides between the egg white and the inner surface of the eggshell (Tsai et al., 2006). The Hen Eggshell Membrane (HESM) consists of interwoven protein fibers and spherical masses (Tsai et al., 2008). The duck egg contains about $11 \%$ eggshell and ESM. It also consists of an inner and an outer membrane with entangled threads or randomly knitted net shapes. The diameter of ESM fiber is less than $0.2 \mu \mathrm{m}$ (Kaewmanee et al., 2009). Furthermore, ESM also consists of yolk spherocrystal with diameter of about $30 \mu \mathrm{m}$ (Tong et al., 2008). The ESM possess a porous and fibril structure, with a very high surface area and special functional groups such as hydroxyl (-OH), thiol (-SH), carboxyl (-COOH), amino $\left(-\mathrm{NH}_{2}\right)$, amide $\left(-\mathrm{CONH}_{2}\right)$ etc., which strongly interact with various chemical species (Mittal et al., 2016). The protein fibers of ESM are arranged to form a semipermeable membrane which possesses an intricate lattice of hierarchically ordered macroporous network of stable and water-insoluble fibers, which also has high surface area (Tsai et al., 2006). It has a high decomposition temperature $\left(>220{ }^{\circ} \mathrm{C}\right)$, enough mechanical strength and low water uptake and swelling properties $(<10 \%)$ (Yu et al., 2012) resulting its use in various applications such as adsorbents (Tsai et al., 2006). The ESM has also been used for adsorption of chlorinated phenols, Direct Red 80 and Acid Blue 25, from aqueous solutions (Guru and Dash, 2014). Since ESM is a highly crosslinked protein structure with excellent permeability to substrates and products (Tembe et al., 2008), it has been used as the substrate and template to immobilize the layered double hydroxide formed by hydrothermal crystallization method and used as adsorbent for $\mathrm{Cr}(\mathrm{VI})$ adsorption (Guo et al., 2011). It has been activated by glutaraldehyde for the immobilization of the enzyme tyrosinase achieved with high effectiveness (Tembe et al., 2008). In general, porous carbon composites containing different metals such as $\mathrm{Fe}, \mathrm{Co}, \mathrm{Pt}, \mathrm{Ag}, \mathrm{Ni}, \mathrm{Sn}, \mathrm{Mn}$, etc. and their species have been synthesized to be used in electrochemical, catalytic, adsorption and other 
applications. Metals and metal oxides in these composites can strongly affect the structural, textural and other characteristics of the materials (Gun'ko et al., 2014). For example, activated carbon from coconut shells has been modified with $10-15 \%$ sodium acetate and used in a fixed-bed column for copper ions removal. The authors have shown that the material could adsorb 33-45 mg of $\mathrm{Cu}$ with $\mathrm{Cu}(\mathrm{II})$ : $\mathrm{Na}$ ratio of $3.85 \mathrm{~mol}: 7.54$ mol (Mugisidi et al., 2007). Zinc acetate has been used as a catalyst for polycondensation and polymer carbonization of resorcinol-formaldehyde mixtures. The mixtures were carbonized at $780-800^{\circ} \mathrm{C}$ to form $\mathrm{ZnO}$ doped chars. The texture of the doped chars depends strongly on the content of $\mathrm{ZnO}$. The chars can be purely nanoporous and composed of micro sized smooth globules with low $\mathrm{ZnO}$ content, or composed of nano-mesoporous particles of 20-100 nm in size with high $\mathrm{ZnO}$ content differently aggregated into secondary meso-macroporous structures (Gun'ko et al., 2014). ZnO micro/nano materials were also hydrothermally grown on activated carbon cloth and used as electrodes in a flow cell for brackish water desalination by capacitive deionization (Myint et al., 2014). In addition, the nano $\mathrm{ZnO} /$ activated carbon composite has been used for tributyltin removal from seawater (Ayanda et al., 2013).

This research studied the effect of activation agents ( $5 \mathrm{wt} \%$ of sodium acetate or zinc metal) and pyrolysis temperature $\left(400-600^{\circ} \mathrm{C}\right)$ on the preparation of carbonized and activated carbon products from duck and hen eggshell membranes. The products were characterized by FTIR, XRD, SEM-EDS and TEM. The percent yields of carbonized products and activated carbons are also calculated.

\section{Materials and Methods}

The eggshell wastes of hen and duck were obtained from local households and were washed with deionized water. The ESMs were then manually removed from outer eggshell and dried in oven (SL shellab, $1350 \mathrm{FX}$, USA) at $120^{\circ} \mathrm{C}$ for $3 \mathrm{~h}$. The dried ESMs were mixed with $5 \mathrm{wt} \%$ of sodium acetate (AR grade) or $\mathrm{Zn}$ metal powder (size 80 mesh, AR grade) by a wet method in aqueous solution. The mixtures were dried in oven at $120^{\circ} \mathrm{C}$ for $3 \mathrm{~h}$. Accurate weights of the dried mixtures were filled into porcelain crucibles which were covered by aluminium foil followed by a lid and then activated in an electric furnace (Fisher Scientific Isotemp ${ }^{\circledR}$ Muffle furnace) at final temperatures of 400,500 and $600^{\circ} \mathrm{C}$ with a constant heating rate of $10^{\circ} \mathrm{C} \mathrm{min}^{-1}$ and a $5 \mathrm{~min}$ soaking time. The dried ESMs were also carbonized at 400,500 and $600^{\circ} \mathrm{C}$. After reaching the final temperature and the soaking time, the final products were cooled to room temperature. The percent yields of all products were then calculated.

\section{Characterizations}

The morphological structure and elemental composition of the dried ESMs, Carbonized Eggshell Membranes (CESMs) and Eggshell Membranes Activated Carbons (ESMACs) were observed and photographed by Scanning Electron Microscopy equipped with Energy Dispersive Spectrometer (SEMEDS, LEO $1455 \mathrm{VP})$. The CESMs and ESMACs were also characterized by X-ray powder diffract meter (PW 3040/60, X' Pert Pro MPD), FTIR (Spectrum GX, Perkin Elmer) and TEM (PHILPS, Tecnai 12).

\section{Results and Discussion}

\section{Percent Yield}

Data in Table 1 show that the percent yields of all products decrease with increase in carbonization or activation temperature. This indicates that the volatile matters such as proteins, carbohydrates and lipids (Ahmed et al., 2017), in ESMs were degraded to a higher extent at higher temperatures. Furthermore, it was seen that all products from Duck Eggshell Membrane (DESM) give higher percent yields than products made from Hen Eggshell Membrane (HESM) made at the same conditions. This may be attributed to $\mathrm{CaCO}_{3}$ and other metal compounds, which show higher content in DESM which than in HESM. The egg shell membranes were decomposed into $\mathrm{CaO}$ and other metal oxides with high content of carbonized or activated products (Table $2)$. Another reason may be the protein content $(80-85 \%)$ of HESM (Baláž, 2014), which is higher than that of DESM. Thus, the HESM undergoes more substantial thermal degradation than DESM. Furthermore, percent yield of all products decreased at a relatively low rate from 400 to $500^{\circ} \mathrm{C}$, but a higher rate from 500 to $600^{\circ} \mathrm{C}$ for both ESMs. This is attributed to the thermal degradation of collagen and glycan chains in the ESMs with a slow rate in the temperature range between 250 and $450^{\circ} \mathrm{C}$ and then with a high mass loss rate at 500$600^{\circ} \mathrm{C}$ (Baláž, 2014; Yu et al., 2012). Additionally, it was found that the percent yields of activated products from both ESMs formed after mixing with $5 \mathrm{wt} \%$ of $\mathrm{CH}_{3} \mathrm{COONa}$ or $\mathrm{Zn}$ metal powder decreased more substantially than CESMs at all temperatures. This shows that both $\mathrm{CH}_{3} \mathrm{COONa}$ and $\mathrm{Zn}$ metal result in higher rate of decomposition of ESMs by partial oxidation in comparison to the carbonization process. The percent yields of ESMACs formed in procedures using mixing with $\mathrm{Zn}$ metal are higher than those formed using mixing with $\mathrm{CH}_{3} \mathrm{COONa}$ at same temperature. This result is attributed to poor solubilities of $\mathrm{ZnO}$ in the reaction mixtures (Simanjuntak et al., 2011) and high thermal degradation of $\mathrm{CH}_{3} \mathrm{COONa}$. 
Table 1. Percent yields of carbonized products and activated carbons from HESM and DESM with carbonization or activation temperature at $400-600^{\circ} \mathrm{C}$

\begin{tabular}{|c|c|c|c|}
\hline \multirow[b]{2}{*}{ Types of samples } & \multicolumn{3}{|c|}{$\%$ Yield } \\
\hline & $400^{\circ} \mathrm{C}$ & $500^{\circ} \mathrm{C}$ & $600^{\circ} \mathrm{C}$ \\
\hline CHESM & 39.41 & 38.48 & 18.62 \\
\hline $\mathrm{CH}_{3} \mathrm{COONa}-\mathrm{HESMAC}$ & 31.81 & 30.03 & 15.23 \\
\hline Zn- HESMAC & 34.29 & 32.15 & 17.99 \\
\hline CDESM & 42.20 & 41.49 & 23.95 \\
\hline $\mathrm{CH}_{3} \mathrm{COONa}-\mathrm{DESMAC}$ & 33.65 & 31.74 & 19.61 \\
\hline Zn-DESMAC & 38.89 & 35.26 & 20.10 \\
\hline
\end{tabular}

Table 2. Elemental composition of $\mathrm{CH}_{3} \mathrm{COONa}-\mathrm{DESMAC}$, Zn-DESMAC, $\mathrm{CH}_{3} \mathrm{COONa-HESMAC}$ and Zn-HESMAC prepared at $600^{\circ} \mathrm{C}$ and obtained from EDS analysis

\begin{tabular}{|c|c|c|c|c|c|c|}
\hline \multirow[b]{2}{*}{ Samples } & \multicolumn{6}{|c|}{ Elements composition (wt\%) } \\
\hline & $\mathrm{C}$ & $\mathrm{O}$ & $\mathrm{Na}$ & $\mathrm{Mg}$ & $\mathrm{Ca}$ & $\mathrm{Zn}$ \\
\hline $\mathrm{CH}_{3} \mathrm{COONa}-\mathrm{DESMAC}$ & 59.63 & 27.26 & 9.59 & 0.80 & 2.78 & - \\
\hline Zn-DESMAC & 61.30 & 19.56 & 2.65 & 0.63 & 2.29 & 13.80 \\
\hline $\mathrm{CH}_{3} \mathrm{COONa}-\mathrm{HESMAC}$ & 83.99 & 10.33 & 4.78 & 0.67 & 0.79 & - \\
\hline Zn-HESMAC & 84.94 & 8.280 & 0.97 & 0.78 & 0.74 & 4.790 \\
\hline
\end{tabular}

\section{FTIR Analysis}

The FTIR spectra of the Carbonized Duck Eggshell Membrane (CDESM) and Duck Eggshell Membrane Activated Carbon (DESMAC) prepared at 400, 500 and $600^{\circ} \mathrm{C}$ are shown in Fig. 1. Figure 1a shows that the FTIR spectrum of CDESM prepared at $400^{\circ} \mathrm{C}$ contains peaks at $3367 \mathrm{~cm}^{-1}(\mathrm{~N}-\mathrm{H}$ bonds or $\mathrm{C}-\mathrm{O}$ asymmetric stretching), $2919 \mathrm{~cm}^{-1}$ (C-H bonds in $=\mathrm{C}-\mathrm{H}$ and $=\mathrm{CH}_{2}$ groups), $1760 \mathrm{~cm}^{-1}(\mathrm{C}=\mathrm{O}$ stretching vibration in carboxylic groups), $1650 \mathrm{~cm}^{-1}$ (amide $\mathrm{C}=\mathrm{O}$ stretching), $1431 \mathrm{~cm}^{-1}(\mathrm{CaO}, \mathrm{C}=\mathrm{C})$ and $712 \mathrm{~cm}^{-1}\left(\mathrm{CO}_{3}^{2-}\right.$ of calcite) (Mami et al., 2008; Baláž et al., 2016; Tan et al., 2015; Botomé et al., 2017; Zaki et al., 2006; Tsai et al., 2006). It contains features that can be attributed to amines, amides, $\mathrm{CaCO}_{3}$, $=\mathrm{C}-\mathrm{H}$ and $=\mathrm{CH}_{2}$, which remained in CDESM after preparation at $400^{\circ} \mathrm{C}$. Especially, carboxylate $\mathrm{CO}_{3}^{2-}$ of $\mathrm{CaCO}_{3}$ is still not completely decomposed after preparation at $400^{\circ} \mathrm{C}$, which is demonstrated by FTIR peaks at 3367,1431 and $712 \mathrm{~cm}^{-1}$ of $\mathrm{C}-\mathrm{O}$ asymmetric stretching and out of plane bending vibration modes (Tan et al., 2015). The peaks indicating the presence of amines and amides in the ESMs are also located at $3367 \mathrm{~cm}^{-1}$ with an additional peak at $1650 \mathrm{~cm}^{-1}$ (Tsai et al., 2006). Thus, the organic components of ESMs are not completely decomposed after the carbonization process carried out at $400^{\circ} \mathrm{C}$. This result is in accord with the percent yields of CESMs at $400^{\circ} \mathrm{C}$ (Table 1), which are higher than those at $500-600^{\circ} \mathrm{C}$. These FTIR peaks of DESM disappeared after carbonization at $500-600^{\circ} \mathrm{C}$ with the exception of the peak at $1431 \mathrm{~cm}^{-1}$. This confirms that the functional groups on surface of the carbon material were burnt off to a large extent after the carbonization at these temperatures. This results in the decrease of the percent yield of carbonized products as well as the activated products (Table 1). The peak at $1431 \mathrm{~cm}^{-1}$ is attributed to $\mathrm{CaO}$ (Zaki et al., 2006), as well as $\mathrm{C}=\mathrm{C}$ stretching of aromatic rings (Nasrollahzadeh et al., 2016). A new peak is observed in CDESM after carbonization at $500-600{ }^{\circ} \mathrm{C}$ at $712 \mathrm{~cm}^{-1}$ (very weak). This peak can be attributed to calcite, which is formed by heating at $500^{\circ} \mathrm{C}$ and is more crystalline than the initial calcium carbonates (López Granados et al., 2007). Materials prepared with $\mathrm{CH}_{3} \mathrm{COONa}$ activation $\left(\mathrm{CH}_{3} \mathrm{COONa}\right.$-DESMACs, Fig. 1d-f) show FTIR spectra with peaks similar to the CDESM, but intensity of these peaks tends to be lower than for CDESM. The intensity of the peaks also decreases with increasing temperature from 400 to $600^{\circ} \mathrm{C}$. Especially, the spectrum of $\mathrm{CH}_{3} \mathrm{COONa}-$ DESMAC prepared at $600^{\circ} \mathrm{C}$ (Fig. 1f) shows peaks only at $1431 \mathrm{~cm}^{-1}$ (strong) and $875 \mathrm{~cm}^{-1}$ (very weak) which are due to $\mathrm{CO}_{3}{ }^{2-}$ species of calcite (Zaki et al., 2006). At $400-500^{\circ} \mathrm{C}$, the FTIR spectra of $\mathrm{CH}_{3} \mathrm{COONa-DESMACs}$ also contain peaks at $1110 \mathrm{~cm}^{-1}$, which are attributed to C-O and C-N (Baláž, 2014; Park et al., 2016). Analogously, FTIR spectra of Zn-DESMAC (Fig. 1g-i) contain peaks similar to $\mathrm{CH}_{3} \mathrm{COONa-DESMAC}$, with the exception of the spectrum of the material prepared at $400^{\circ} \mathrm{C}$ (Fig. 1g). The spectrum of $\mathrm{Zn}$-DESMAC prepared at $400^{\circ} \mathrm{C}$ also contains peaks at $3367 \mathrm{~cm}^{-1}, 2919,1700,1600,1431,1350 \mathrm{~cm}^{-1}$ (C$\mathrm{OH}$, Kashinath et al., 2016) and $1110 \mathrm{~cm}^{-1}$. These peaks also disappeared after activation at 500 and $600^{\circ} \mathrm{C}$ (Fig. 1hi) where the remaining of peaks are found at 1431, 875 and $720 \mathrm{~cm}^{-1}$. These peaks remaining after activation at $600^{\circ} \mathrm{C}$ are also attributed to $\mathrm{CO}_{3}{ }^{2-}$ of calcite. It should be noted that calcite is usually completely decomposed into $\mathrm{CaO}$ above $700^{\circ} \mathrm{C}$ (Zaki et al., 2006). However, the peaks of $\mathrm{C}=\mathrm{C}, \mathrm{Na}-$ $\mathrm{O}$ and C-O stretching (Magdziarz et al., 2016) are also located at $1431 \mathrm{~cm}^{-1}$, which has caused the peak at 1431 $\mathrm{cm}^{-1}$ to remain with high intensity for all activated 
products. The FTIR spectra of CHESMs (Fig. 2a-c), $\mathrm{CH}_{3} \mathrm{COONa-HESMACs}$ (Fig. 2d-f) and Zn-HESMACs (Fig. 2g-i) show similar trends to the FTIR spectra of corresponding DESM materials. The analysis of the FTIR spectra revealed that the $\mathrm{CH}_{3} \mathrm{COONa}$ and $\mathrm{Zn}$ activations have no effect on the type of functional groups found on activated carbon products made both from DESM and HESM, but they accelerated the decomposition or modification of functional groups on surface of ESMACs. Based on the FTIR results, it can be concluded that the suitable activation temperature for the preparation of ESMs lies in the range $500-600^{\circ} \mathrm{C}$, which is in line with the report of Rath et al. (2014).

\section{Elements Analysis by EDS}

The elemental composition of $\mathrm{CH}_{3} \mathrm{COONa}-$ DESMAC, Zn-DESMAC, $\mathrm{CH}_{3} \mathrm{COONa-HESMAC} \mathrm{and}$ $\mathrm{Zn}$-HESMAC prepared at $600^{\circ} \mathrm{C}$, was obtained using EDS analysis. The results are shown in Table 2 and they indicate high carbon content in all of the materials. These results confirm that the ESMs have been converted into carbon during the activation process. Moreover, it can be seen that the carbon content in HESMACs for both activation reagents is higher than that of the DESMACs. This is because HESM has higher content of organic compounds than DESM, which are converted to carbon during high temperature degradation under partial oxidation conditions. Furthermore, it can be seen that $\mathrm{CH}_{3} \mathrm{COONa-DESMAC}$ and $\mathrm{Zn}$-DESMAC have higher metal content than $\mathrm{CH}_{3} \mathrm{COONa-HESMAC}$ and $\mathrm{Zn}$-HESMAC which is in line with results of percent yield reported in Table 1 . The oxygen content of all activated carbon materials is quite high, indicating high content of oxygen containing functional groups and metals oxides on surface of the activated carbon materials. Especially, oxygen content in $\mathrm{CH}_{3} \mathrm{COONa}$ DESMAC is very high $(27.26 \%)$, which could in part originate from the $\mathrm{CH}_{3} \mathrm{COONa}$ activating agent. Calcium shows higher content in activated carbon materials from DESM than those from HESM. These results are also in line with the FTIR results (Fig. 1 and 2). The content of $\mathrm{Na}$ in $\mathrm{CH}_{3} \mathrm{COONa-DESMAC}$ and $\mathrm{CH}_{3} \mathrm{COONa-HESMAC}$ and $\mathrm{Zn}$ in $\mathrm{Zn}$-DESMAC and $\mathrm{Zn}$-HESMAC are quite high. This is because of the $\mathrm{CH}_{3} \mathrm{COONa}$ and $\mathrm{Zn}$ that were added to the ESMs for activation, which contain $\mathrm{Na}$ and $\mathrm{Zn}$ that remain in the activated products. The $\mathrm{Mg}$ present in the final materials originated from starting ESMs.

\section{XRD Analysis}

The XRD patterns of carbonized and activated products made from DESM and HESM display a peak at $2 \theta=25.5^{\circ}$, which is assigned as the crystallographic planes of graphitic layers with disordered graphite carbon structure (Fig. 3a-f). In addition, a weak peak located at $44^{\circ}$ is attributed to amorphous carbon (Pant et al., 2017). These results confirm that the organic materials originally present in the ESMs have been converted into carbon for all produced materials thus supporting the high carbon content of carbonized and activated products as shown in Table 2. Furthermore, the XRD patterns also show crystalline peaks of calcite, which remained in final products after carbonization or activation, at $2 \theta=23,29.5,34.2,36,39.5,43.2,48.5$, $57.5,60.5,63,64.5,72$ and $81.5^{\circ}$ (Slimani et al., 2014).

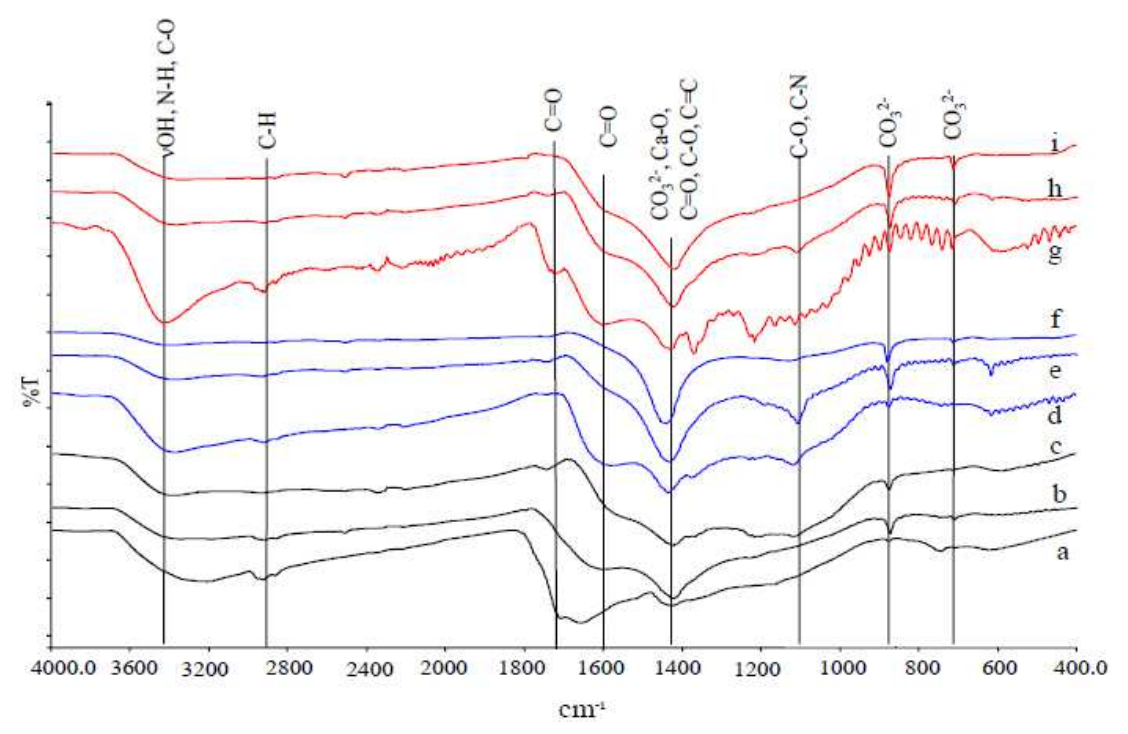

Fig. 1. FTIR transmittance spectra of (a) CDESM prepared at $400^{\circ} \mathrm{C}$, (b) CDESM prepared at $500^{\circ} \mathrm{C}$, (c) $\mathrm{CDESM}$ prepared at $600^{\circ} \mathrm{C}$, (d) $\mathrm{CH}_{3} \mathrm{COONa-DESMAC}$ prepared at $400^{\circ} \mathrm{C}$, (e) $\mathrm{CH}_{3} \mathrm{COONa}$-DESMAC prepared at $500^{\circ} \mathrm{C}$, (f) $\mathrm{CH}_{3} \mathrm{COONa}$ - DESMAC prepared at $600^{\circ} \mathrm{C}$, (g) Zn-DESMAC prepared at $400^{\circ} \mathrm{C}$, (h) Zn-DESMAC prepared at $500^{\circ} \mathrm{C}$ and (i) $\mathrm{Zn}-$ DESMAC prepared at $600^{\circ} \mathrm{C}$ 


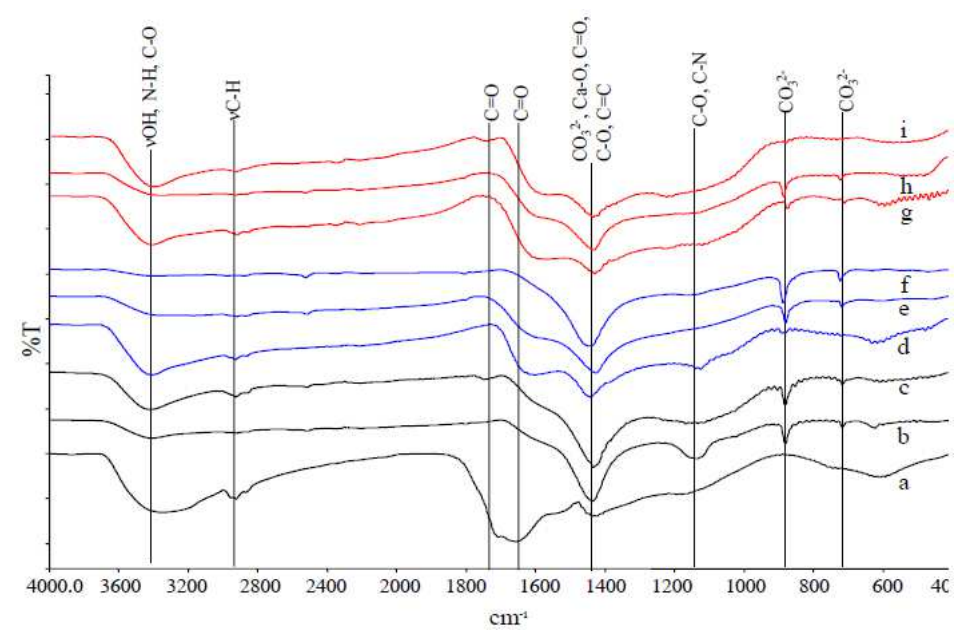

Fig. 2. FTIR transmittance spectra of (a) CHESM prepared at $400^{\circ} \mathrm{C}$, (b) CHESM prepared at $500^{\circ} \mathrm{C}$, (c) CHESM prepared at $600^{\circ} \mathrm{C}$, (d) $\mathrm{CH}_{3} \mathrm{COONa}-\mathrm{HESMAC}$ prepared at $400^{\circ} \mathrm{C}$, (e) $\mathrm{CH}_{3} \mathrm{COONa}$-HESMAC prepared at $500^{\circ} \mathrm{C}$, (f) $\mathrm{CH}_{3} \mathrm{COONa}$ - HESMAC prepared at $600^{\circ} \mathrm{C}$, (g) Zn-HESMAC prepared at $400^{\circ} \mathrm{C}$, (h) Zn-HESMAC prepared at $500^{\circ} \mathrm{C}$ and (i) Zn- HESMAC prepared at $600^{\circ} \mathrm{C}$

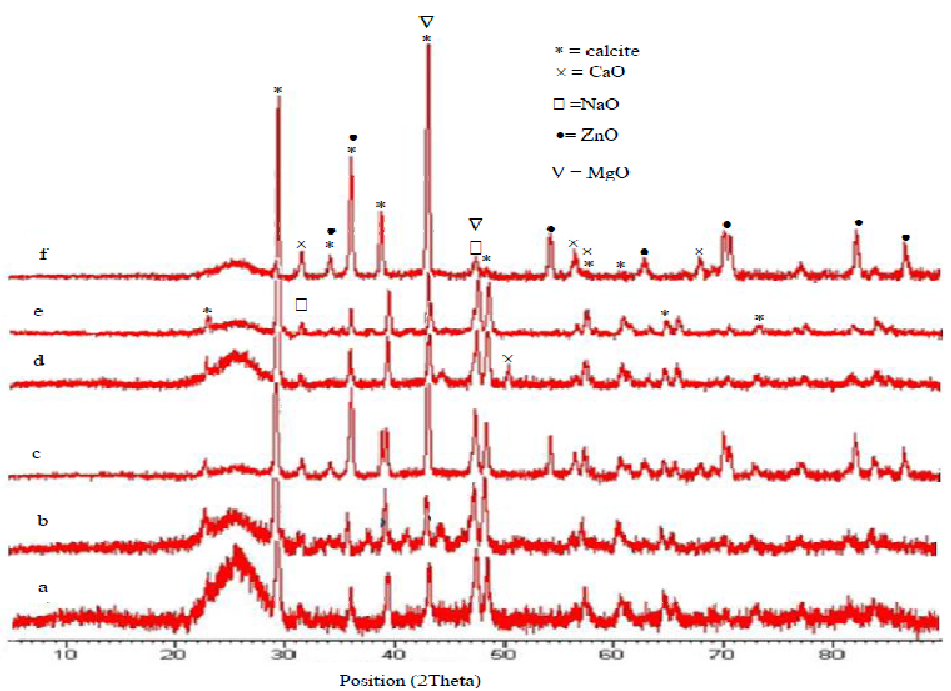

Fig. 3. XRD patterns of (a) CDESM, (b) $\mathrm{CH}_{3} \mathrm{COONa-DESMAC,} \mathrm{(c)} \mathrm{Zn-DESMAC,} \mathrm{(d)} \mathrm{CHESM,} \mathrm{(e)} \mathrm{CH}_{3} \mathrm{COONa-HESMAC} \mathrm{and} \mathrm{(f)}$ $\mathrm{Zn}$-HESMAC prepared at $600^{\circ} \mathrm{C}$

The XRD peaks at $31.5,40.5,50.2,54$ and $57.5^{\circ}$ are attributed to $\mathrm{CaO}$ (Mohammadi et al., 2014), which was formed from $\mathrm{CaCO}_{3}$ by thermal degradation. XRD peaks of $\mathrm{NaO}$, which formed from $\mathrm{CH}_{3} \mathrm{COONa}$ by thermal degradation, are located at 32.1 and $47.4^{\circ}$ (Magdziarz et al., 2016). The peaks present at 43,49 and $75^{\circ}$ are attributed to $\mathrm{MgO}$, which originated from oxidation of $\mathrm{Mg}$ compounds found in the starting ESMs. Finally, the $\mathrm{XRD}$ diffraction peaks belonging to $\mathrm{ZnO}$, which originated from oxidation of the $\mathrm{Zn}$ metal powder in $\mathrm{Zn}$ DESMAC (Fig. 3c) and Zn-HESMAC (Fig. 3f), are located at $2 \theta=31.7,34.4,36.2,47.5,56.6,62.8,66.3$, 67.9 and $69.1^{\circ}$ (Kashinath et al., 2016). The intensities of XRD peaks of $\mathrm{Na}_{2} \mathrm{O}$ and $\mathrm{ZnO}$ in the activated products are higher after $\mathrm{CH}_{3} \mathrm{COONa}$ and $\mathrm{Zn}$ addition in comparison to products prepared without $\mathrm{CH}_{3} \mathrm{COONa}$ and $\mathrm{Zn}$ additives carbonized. These XRD results correspond to FTIR and EDS data presented in Fig. 1 and 2 and Table 2.

\section{SEM Analysis}

The SEM images of the fresh DESM, CDESMs, $\mathrm{CH}_{3} \mathrm{COONa-DESMACs}$ and $\mathrm{Zn}$-DESMACs are shown in Fig. 4. The fresh DESM (Fig. 4a) shows a hierarchically ordered macroporous network and some microporous structures on the surface. After carbonization, the CDESMs show a network like structure with an aggregation of particles on the surface (Fig. 4b-d). The surfaces of CDESMs are quite smooth. The amount and size of particles on the surfaces of CDESMs decrease as the carbonization temperature is increased. 

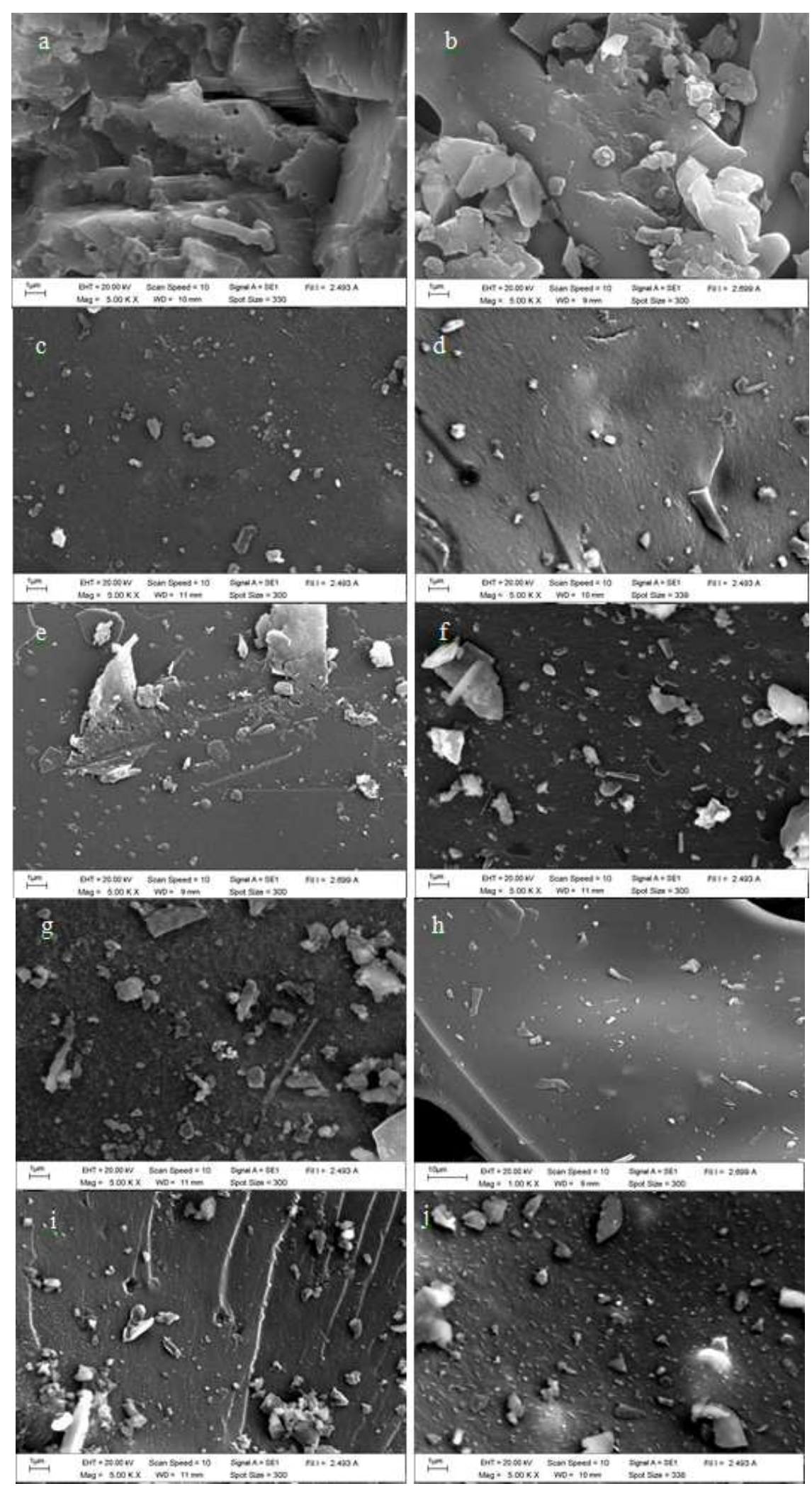

Fig. 4. Morphologies of (a) fresh DESM, (b) CDESM prepared at $400^{\circ} \mathrm{C}$, (c) CDESM prepared at $500^{\circ} \mathrm{C}$, (d) CDESM prepared at $600^{\circ} \mathrm{C}$, (e) $\mathrm{CH}_{3} \mathrm{COONa}-\mathrm{DESMAC}$ prepared at $400^{\circ} \mathrm{C}$, (f) $\mathrm{CH}_{3} \mathrm{COONa}-\mathrm{DESMAC}$ prepared at $500^{\circ} \mathrm{C}$, (g) $\mathrm{CH}_{3} \mathrm{COONa}-\mathrm{DESMAC}$ prepared at $600^{\circ} \mathrm{C}$, (h) Zn-DESMAC prepared at $400^{\circ} \mathrm{C}$, (i) Zn-DESMAC prepared at $500^{\circ} \mathrm{C}$ and (j) Zn-DESMAC prepared at $600^{\circ} \mathrm{C}$ 
The size of particles on the surface of CDESMs is 0.27 $3.73,0.09-1.18$ and $0.05-1 \mu \mathrm{m}$ for materials prepared at 400, 500 and $600{ }^{\circ} \mathrm{C}$, respectively. This shows that the volatile compounds in DESM undergo a more extensive thermal degradation as higher carbonization temperatures. The activated products exhibit a more extensive thermal degradation than the CDESMs at same temperature (Fig. 4e-j). The $\mathrm{CH}_{3} \mathrm{COONa-DESMACs}$ (Fig. 4e-g) show more open, porous and rough surfaces with spherical particles for activation at $500-600^{\circ} \mathrm{C}$. The spherical particles with a diameter of about $90.9 \mathrm{~nm}$ are due to sodium oxide. However, the surface of $\mathrm{CH}_{3} \mathrm{COONa-DESMAC}$ obtained with activation at $400^{\circ} \mathrm{C}$ does not show open porous structures. This indicates that the $\mathrm{CH}_{3} \mathrm{COONa-DESMAC}$ prepared with activation at $400^{\circ} \mathrm{C}$ show small extent of degradation and partial oxidation. Furthermore, it was seen that the spherical particles on the surfaces $\mathrm{CH}_{3} \mathrm{COONa}$ DESMAC are firmly attached. This might be due to the fact that $\mathrm{CH}_{3} \mathrm{COONa}$ can incorporate with proteins present in the ESMs fibers (Camaratta et al., 2015). The amount of spherical particles and particles with uncertain shape increases as the activation temperature is increased, with especially high content at $600^{\circ} \mathrm{C}$. This is because of volatile matters being degraded while $\mathrm{Na}_{2} \mathrm{O}$, $\mathrm{CaO}$ and some other metal oxides dominate the surface. Likewise, Zn-DESMACs (Fig. 4h-j) show high thermal degradation in comparison to CDESMs prepared at the same temperature. This result is related to the percent yield data in Table 1. At the activation temperature of $400^{\circ} \mathrm{C}$, the smooth and quite clear surface containing only some particles is observed for Zn-DESMAC. However, Zn-DESMACs prepared at $500-600^{\circ} \mathrm{C}$ show surfaces with higher amounts of particles of various sizes in comparison to the material prepared at $400^{\circ} \mathrm{C}$. It can be seen that the particles on Zn-DESMACs surface are attached more weakly than those on the surface of $\mathrm{CH}_{3} \mathrm{COONa-DESMACs}$ prepared at the same temperature. This is attributed to low solubility of $\mathrm{Zn}$ metal in the reaction mixtures (Simanjuntak et al., 2011). After activation at $600^{\circ} \mathrm{C}$ the Zn-DESMAC surface contains a high number of small particles that are regularly dispersed. Some large size particles can also be found on its surface (Fig. $4 \mathrm{j}$ ).

Figure 5 shows the morphology of structures of the fresh HESM, CHESM, $\mathrm{CH}_{3} \mathrm{COONa-HESMAC} \mathrm{and}$ Zn-HESMAC. The morphology of fresh HESM (Fig. 5a) shows smooth interwoven fibers with some knobs and no porous structures on its surface. This is because the eggshell membrane mainly consists of fibrous or collagen like proteins (Tsai et al., 2006). The diameter size of fresh HESM fiber is in the range of 1.71 to $4.86 \mu \mathrm{m}$. After carbonization at $400^{\circ} \mathrm{C}$ (Fig. 5b), CHESM shows smooth surface with some particles (0.23-10 $\mu \mathrm{m}$ diameter) and macroporous cavities $(0.45-7.73 \mu \mathrm{m}$ diameter). This shows that the volatile compounds, which coat the fibers, were thermally decomposed during the carbonization process. At this stage only the membrane matrix remained. After that, the rough characteristics with some differences in particle size (0.09-4.86 $\mu \mathrm{m}$ diameter) on the CHESM surface were observed after activation at $500^{\circ} \mathrm{C}$ (Fig. 5c). However, CHESM prepared at $600^{\circ} \mathrm{C}$ shows high amount of microporous structures with a small amount of differently sized particles (0.09-0.82 $\mu \mathrm{m}$ diameter) on the surface. After activation with $\mathrm{CH}_{3} \mathrm{COONa}$, the materials show that particles with differing sizes (0.05-4.82 $\mu \mathrm{m})$ and shapes have accumulated on $\mathrm{CH}_{3} \mathrm{COONa}$-HESMAC at $400^{\circ} \mathrm{C}$ (Fig. 5e) to a greater extent than to which they formed on the surfaces of CHESMs. As the activation temperature is increased (from 500 to $600^{\circ} \mathrm{C}$ ) a substantial amount of regularly dispersed small sized particles are formed on the surface of the HESMACs (Fig. 5f-g). A small amount of large particles also form on these products. It has been seen that the particles on HESMAC prepared at $600^{\circ} \mathrm{C}$ (Fig. 5f) became spherical in shape and larger in size $(214.9-574.1 \mathrm{~nm})$ in comparison to HESMAC prepared at $500^{\circ} \mathrm{C}(90.9-272 \mathrm{~nm}$ in diameter size) (Fig. 5g). However, quite clear and smooth surface with some rough character and particles was observed for $\mathrm{Zn}$-HESMAC prepared at $400^{\circ} \mathrm{C}$. Similarly, the high amount of differently sized particles (0.05-1.91 $\mu \mathrm{m})$ were formed on $\mathrm{Zn}$-HESMAC surface for the material prepared at $500^{\circ} \mathrm{C}$ (Fig. 5i). Furthermore, the high amount of spherical particles (about $45 \mathrm{~nm}$ diameter) with some large particles $(0.182-2.091 \mu \mathrm{m}$ diameter) was also observed on Zn-HESMAC surface for the material prepared at $600^{\circ} \mathrm{C}$ (Fig. 5j). These results indicated that $\mathrm{Na}_{2} \mathrm{O}$ and $\mathrm{ZnO}$ accumulated on the surface of HESMACs after activation.

\section{TEM Analysis}

The TEM images shown in Fig. 6a and e reveal that the CDESM and CHESM prepared at $500^{\circ} \mathrm{C}$ consist of an amorphous carbon matrix. For material prepared with activation by $\mathrm{CH}_{3} \mathrm{COONa}\left(\right.$ at $500-600^{\circ} \mathrm{C}$ ) and $\mathrm{Zn}$ (at $500^{\circ} \mathrm{C}$ ), the TEM images of the activated products show some disordered graphite carbon matrix (Fig. $6 \mathrm{~b}-\mathrm{d}$ and f). Furthermore, it was seen that $\mathrm{CH}_{3} \mathrm{COONa}-\mathrm{HESMAC}$ prepared at $600^{\circ} \mathrm{C}$ (Fig. 6g) and $\mathrm{Zn}$-HESMAC prepared at $500^{\circ} \mathrm{C}$ (Fig. 6h) show an amorphous carbon matrix with spherical particles (diameter of $68-578 \mathrm{~nm}$ ) and nanofiber (diameter range of 13.51-43.24 nm), respectively. These results are consistent with XRD and SEM results. 

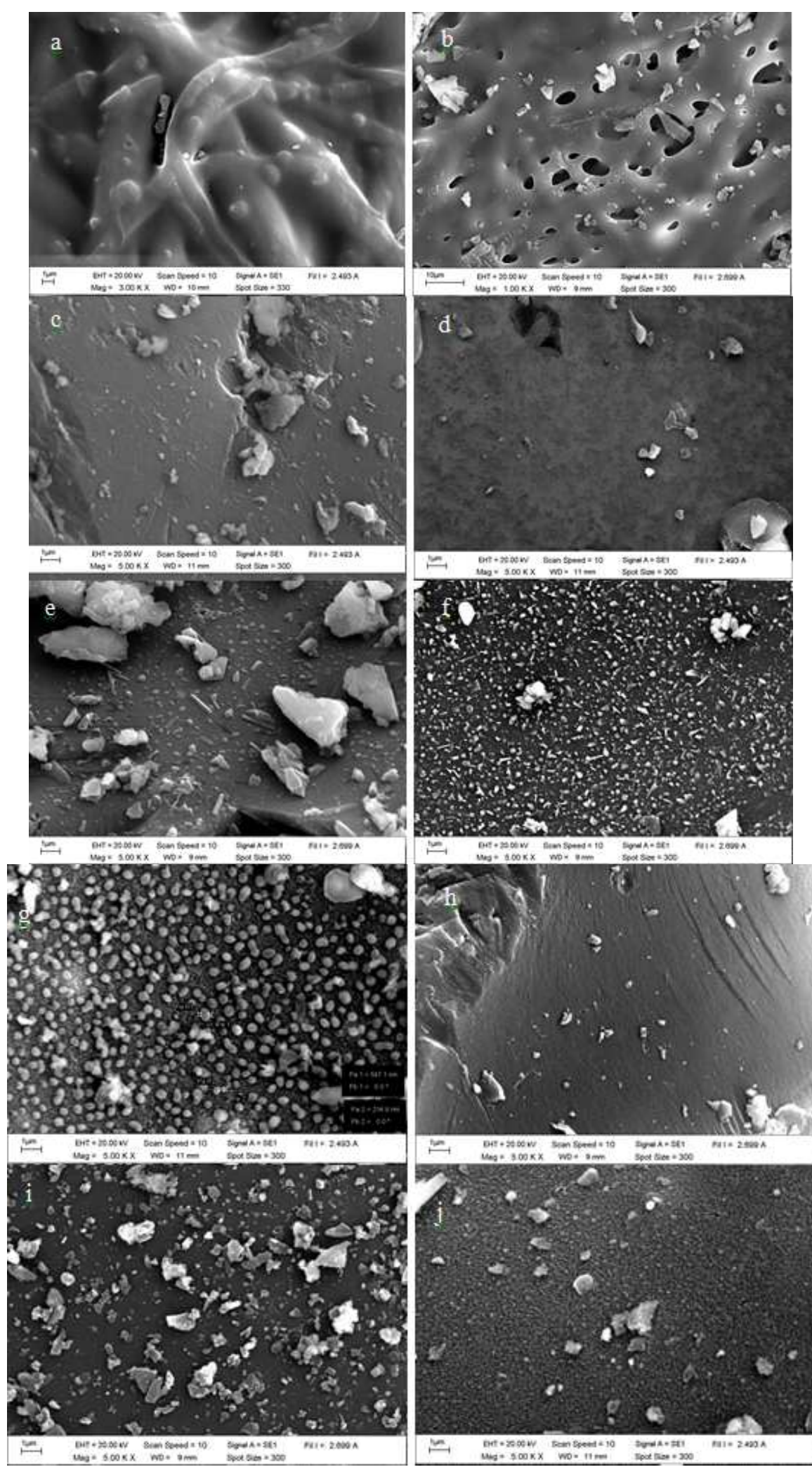

Fig. 5. Morphologies of (a) fresh HESM, (b) CHESM prepared at $400^{\circ} \mathrm{C}$, (c) CHESM prepared at $500^{\circ} \mathrm{C}$, (d) CHESM prepared at $600^{\circ} \mathrm{C}$, (e) $\mathrm{CH}_{3} \mathrm{COONa}-\mathrm{HESMAC}$ prepared at $400^{\circ} \mathrm{C}$, (f) $\mathrm{CH}_{3} \mathrm{COONa}$-HESMAC prepared at $500^{\circ} \mathrm{C}$, (g) $\mathrm{CH}_{3} \mathrm{COONa-HESMAC}$ prepared at $600^{\circ} \mathrm{C}$, (h) Zn-HESMAC prepared at $400^{\circ} \mathrm{C}$, (i) Zn-HESMAC prepared at $500^{\circ} \mathrm{C}$ and (j) $\mathrm{Zn}$-HESMAC prepared at $600^{\circ} \mathrm{C}$ 


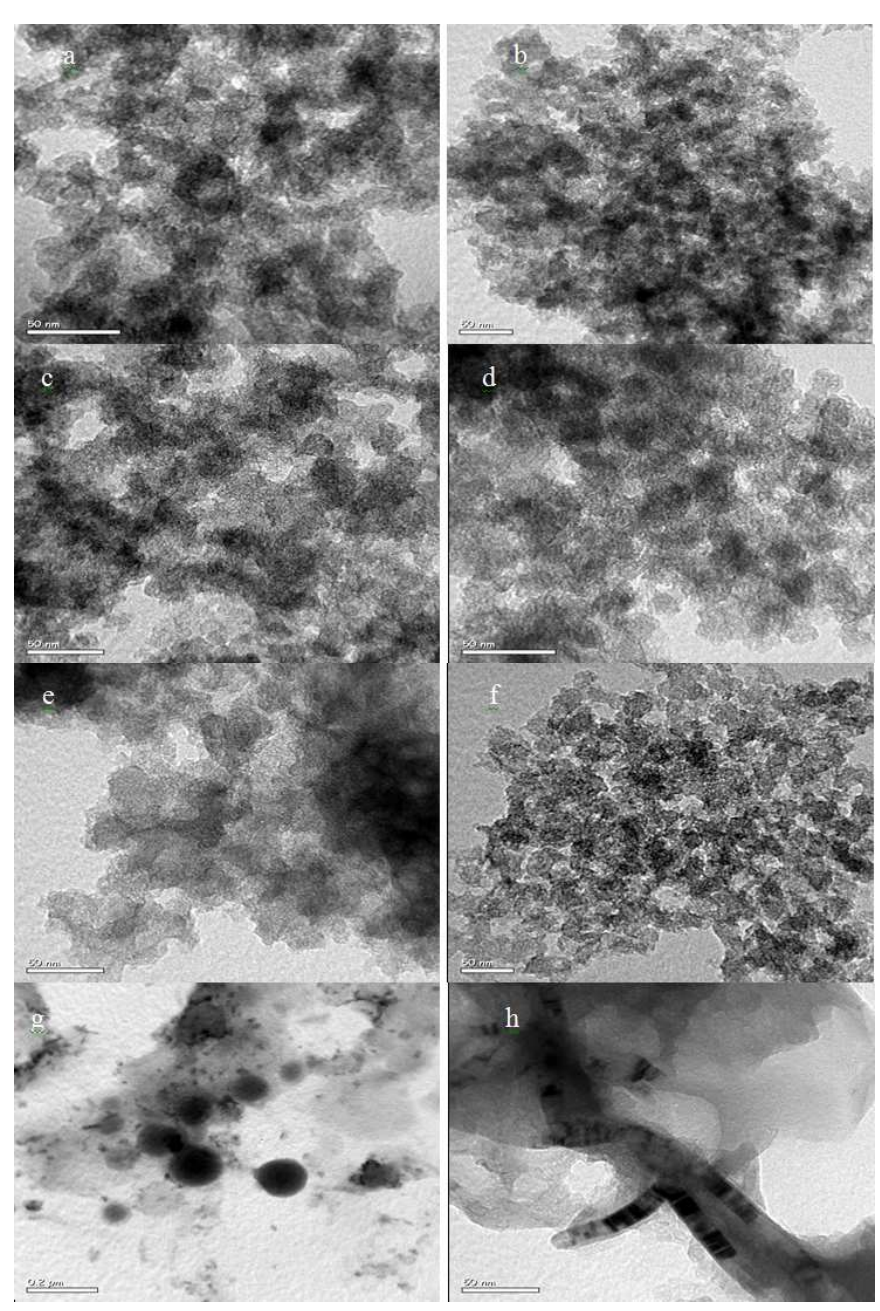

Fig. 6. TEM of (a) CDESM prepared at $500^{\circ} \mathrm{C}$, (b) $\mathrm{CH}_{3} \mathrm{COONa-DESMAC}$ prepared at $500^{\circ} \mathrm{C}$, (c) $\mathrm{CH}_{3} \mathrm{COONa-DESMAC}$ prepared at $600^{\circ} \mathrm{C}$, (d) $\mathrm{Zn}$-DESMAC prepared at $500^{\circ} \mathrm{C}$, (e) CHESM prepared at $500^{\circ} \mathrm{C}$, (f) $\mathrm{CH}_{3} \mathrm{COONa}-\mathrm{HESMAC}$ prepared at $500^{\circ} \mathrm{C}$, (g) $\mathrm{CH}_{3} \mathrm{COONa}-\mathrm{HESMAC}$ prepared at $600^{\circ} \mathrm{C}$ and $(\mathrm{h}) \mathrm{Zn}-\mathrm{HESMAC}$ prepared at $500^{\circ} \mathrm{C}$

\section{Conclusion}

It was concluded, based on the experimental results, that the percent yields of all carbonized and activated products have decreased with increasing carbonization or activation temperature. The results also show that all products prepared from DESM have percent yields higher than products prepared from HESM at the same conditions. There was a small relative decrease in the yield between 400 and $500^{\circ} \mathrm{C}$ followed by a high yield decrease between 500 and $600^{\circ} \mathrm{C}$. The percent yields of ESMACs prepared using mixing with $\mathrm{Zn}$ metal were higher than those prepared using mixing with $\mathrm{CH}_{3} \mathrm{COONa}$ at same temperature. The results have shown that some organic functionalities such as amines, amides, $\mathrm{CO}_{3}^{2-}$, = $\mathrm{C}-\mathrm{H}$ and $=\mathrm{CH}_{2}$ groups still remain in CDESM after preparation at $400^{\circ} \mathrm{C}$. It was shown that carboxylate of $\mathrm{CaCO}_{3}$ is still incompletely decomposed after treatment at all activation temperatures. The $\mathrm{C}=\mathrm{C}$,
$\mathrm{Na}-\mathrm{O}$ and $\mathrm{C}-\mathrm{O}$ functional groups were also observed in ESMACs. Furthermore, it was shown that the $\mathrm{CH}_{3} \mathrm{COONa}$ and $\mathrm{Zn}$ activation modes have no effect on the type of functional groups formed on the activated carbon products from both DESM and HESM. However, the additives have accelerated the decomposition or modification of functional groups on the surfaces of ESMACs. EDS analysis has shown that the HESMAC materials are mainly composed of carbon for both activation reagents and that their carbon content is higher than of the corresponding DESMACs. In addition, all activated carbon materials have quite high oxygen content, which is exhibited in high content of oxygen containing functional groups and metals oxide compound on the surfaces of the activated carbon materials. The XRD and TEM results of carbonized and activated products made from DESM and HESM displayed disordered graphite carbon structures and amorphous carbon. XRD patterns of ESMACs also showed crystalline calcite, $\mathrm{CaO}, \mathrm{MgO}, \mathrm{ZnO}$ 
and $\mathrm{Na}_{2} \mathrm{O}$. The TEM images of $\mathrm{CH}_{3} \mathrm{COONa}-$ HESMAC prepared at $600^{\circ} \mathrm{C}$ and Zn-HESMAC prepared at $500^{\circ} \mathrm{C}$ also show spherical particles (68$578 \mathrm{~nm}$ diameter) and nanofibers (13.51-43.24 nm diameter). The SEM morphologies of CDESMs are quite smooth but containing some particles. The amount and size of particles on the surfaces of CDESMs decrease as the carbonization temperature is increased. After activation at $500-600^{\circ} \mathrm{C}$, ESMACs showed more open, porous and rough surface with spherical particles of sodium oxide or $\mathrm{ZnO}$. It was seen that the particles on Zn-DESMACs are less firmly attached on the surface than those on $\mathrm{CH}_{3} \mathrm{COONa}$-DESMACs formed at the same activation temperature. Finally, it was also shown that the activation activity of $\mathrm{CH}_{3} \mathrm{COONa}$ is stronger than that of $\mathrm{Zn}$ metal for ESMACs preparation. The characteristics of ESMACs observed in this study show that ESMACs can be considered for use as adsorbents for the removal the pollutants from water and other applications to achieve low-cost and also reduction of costs for waste disposal.

\section{Acknowledgement}

The authors acknowledge Science Lab Center, Faculty of Science, Naresuan University for all of the analyses.

\section{Funding Information}

This research was supported by the Department of Chemistry and Faculty of Science, Naresuan University.

\section{Author's Contributions}

Sumrit Mopoung: Designed the research plan, organized the study and wrote of all paragraphs.

Kanjana Jitchaijaroenkul: Co-researchers who have reported and analyzed data presented in this paper.

\section{Ethics}

This article is original and contains unpublished material. The corresponding author confirms that all of the other authors have read and approved the manuscript and no ethical issues are involved.

\section{References}

Ahmed, T.A.E., H.P. Suso and M.T. Hincke, 2017. Indepth comparative analysis of the chicken eggshell membrane proteome. J. Proteomics, 155: 49-62.

Ayanda, O.S., O.S. Fatoki, F.A. Adekola and B.J. Ximba, 2013. Kinetics and equilibrium models for the sorption of tributyltin to $\mathrm{nZnO}$, activated carbon and $\mathrm{nZnO} /$ activated carbon composite in artificial seawater. Mar. Pollut. Bull., 72: 222-230.
Baláž, M., 2014. Eggshell membrane biomaterial as a platform for applications in materials science. Acta Biomater., 10: 3827-3843.

Baláž, M., J. Ficeriová and J. Briančin, 2016. Influence of milling on the adsorption ability of eggshell waste. Chemosphere, 146: 458-471.

Botomé, M.L., P. Poletto, J. Junges, D. Perondi and A. Dettmer et al., 2017. Preparation and characterization of a metal-rich activated carbon from CCA-treated wood for $\mathrm{CO}_{2}$ capture. Chem. Eng. J., 321: 614-621.

Camaratta, R., J.O. Messana and C.P. Bergmann, 2015. Synthesis of $\mathrm{ZnO}$ through biomimetization of eggshell membranes using different precursors and its characterization. Ceram. Int., 41: 14826-14833. DOI: 10.1016/j.ceramint.2015.08.005

Gun'ko, V.M., V.M. Bogatyrov, O.I. Oranska, I.V. Urubkov and R. Leboda et al., 2014. Synthesis and characterization of resorcinol-formaldehyde resin chars doped by zinc oxide. Applied Surf. Sci., 303: 263-271. DOI: 10.1016/j.apsusc.2014.02.164

Guo, X., F. Zhang, Q. Peng, S. Xu and X. Lei et al., 2011. Layered double hydroxide/eggshell membrane: An inorganic biocomposite membrane as an efficient adsorbent for $\mathrm{Cr}(\mathrm{VI})$ removal. Chem. Eng. J., 166: 81-87.

Guru, P.S. and S. Dash, 2014. Sorption on eggshell waste-A review on ultrastructure, biomineralization and other applications. Adv. Colloid Interfac., 209: 49-67.

Kashinath, L., K. Namratha and K. Byrappa, 2016. Microwave assisted synthesis and characterization of nanostructure zinc oxide-graphene oxide and photo degradation of Brilliant Blue. Mater. Today Proc., 3: 74-83.

Kaewmanee, T., S. Benjakul and W. Visessanguan, 2009. Changes in chemical composition, physical properties and microstructure of duck egg as influenced by salting. Food Chem., 112: 560-569.

López Granados, M., M.D.Z. Poves, D.M. Alonso, R. Mariscal and F.C. Galisteo et al., 2007. Biodiesel from sunflower oil by using activated calcium oxide. Applied Catal. B-Environ., 73: 317-326.

Magdziarz, A., A.K. Dalai and J.A. Koziński, 2016. Chemical composition, character and reactivity of renewable fuel ashes. Fuel, 176: 135-145.

Mami, M., A. Lucas-Girot, H. Oudadesse, R. DorbezSridi and F. Mezahi et al., 2008. Investigation of the surface reactivity of a sol-gel derived glass in the ternary system $\mathrm{SiO}_{2}-\mathrm{CaO}-\mathrm{P}_{2} \mathrm{O}_{5}$. Applied Surf. Sci., 254: 7386-7393.

Mittal, A., M. Teotia, R.K. Soni and J. Mittal, 2016. Applications of egg shell and egg shell membrane as adsorbents: A review. J. Mol. Liq., 223: 376-387. DOI: $10.1016 /$ j.molliq.2016.08.065 
Mohammadi, M., P. Lahijani and A.R. Mohamed, 2014. Refractory dopant-incorporated $\mathrm{CaO}$ from waste eggshell as sustainable sorbent for $\mathrm{CO}_{2}$ capture: Experimental and kinetic studies. Chem. Eng. J., 243: 455-464. DOI: 10.1016/j.cej.2014.01.018

Mugisidi, D., A. Ranaldo, J.W. Soedarsono and M. Hikam, 2007. Modification of activated carbon using sodium acetate and its regeneration using sodium hydroxide for the adsorption of copper from aqueous solution. Carbon, 45: 1081-1084.

Myint, M.T.Z., S.H. Al-Harthi and J. Dutta, 2014. Brackish water desalination by capacitive deionization using zinc oxide micro/nanostructures grafted on activated carbon cloth electrodes. Desalination, 344: 236-242.

Nasrollahzadeh, M., S.M. Sajadi and A. Hatamifard, 2016. Waste chicken eggshell as a natural valuable resource and environmentally benign support for biosynthesis of catalytically active $\mathrm{Cu} /$ eggshell, $\mathrm{Fe}_{3} \mathrm{O}_{4}$ /eggshell and $\mathrm{Cu} / \mathrm{Fe}_{3} \mathrm{O}_{4} /$ eggshell nanocomposites. Applied Catal. B Environ., 191: 209-227.

Pant, B., M. Park, H.Y. Kim and S.J. Park, 2017. CdS$\mathrm{TiO}_{2}$ NPs decorated carbonized eggshell membrane for effective removal of organic pollutants: A novel strategy to use a waste material for environmental remediation. J. Alloy. Compd., 699: 73-78.

Park, S., K.S. Choi, D. Lee, D. Kim and K.T. Lim et al., 2016. Eggshell membrane: Review and impact on engineering. Biosys. Eng., 151: 446-463.

Rath, M.K., B.H. Choi, M.J. Ji and K.T. Lee, 2014. Eggshell membrane-templated synthesis of hierarchically-ordered $\mathrm{NiO}-\mathrm{Ce}_{0.8} \mathrm{Gd}_{0.2} \mathrm{O}_{1.9}$ composite powders and their electrochemical performances as SOFC anodes. Ceram. Int., 40: 3295-3304.

Simanjuntak, F.S.H., T.K. Kim, S.D. Lee, B.S. Ahn and H.S. Kim et al., 2011. CaO-catalyzed synthesis of glycerol carbonate from glycerol and dimethyl carbonate: Isolation and characterization of an active Ca species. Applied Catal. A Gen., 401: 220-225. DOI: 10.1016/j.apcata.2011.05.024
Slimani, R., I.E. Ouahabi, F. Abidi, M.E. Haddad and A. Regti et al., 2014. Calcined eggshells as a new biosorbent to remove basic dye from aqueous solutions: Thermodynamics, kinetics, isotherms and error analysis. J. Taiwan Inst. Chem. E., 45: 1578-1587. DOI: 10.1016/j.jtice.2013.10.009

Tan, Y.H., M.O. Abdullah, C. Nolasco-Hipolito and Y.H. Taufiq-Yap, 2015. Waste ostrich- and chickeneggshells as heterogeneous base catalyst for biodiesel production from used cooking oil: Catalyst characterization and biodiesel yield performance. Applied Energ., 160: 58-70.

Tembe, S., B.S. Kubal, M. Karve and S.F. D'Souza, 2008. Glutaraldehyde activated eggshell membrane for immobilization of tyrosinase from Amorphophallus companulatus: Application in construction of electrochemical biosensor for dopamine. Anal. Chim. Acta, 612: 212-217.

Tong, H., P. Wan, W. Ma, G. Zhong and L. Cao et al., 2008. Yolk sperocrystal: The structure, composition and liquid crystal template. J. Struct. Biol., 136: 1-9.

Tsai, W.T., J.M. Yang, C.W. Lai, Y.H. Cheng and C.C. Lin et al., 2006. Characterization and adsorption properties of eggshells and eggshell membrane. Bioresource Technol., 97: 488-493.

Tsai, W.T., K.J. Hsien, H.C. Hsu, C.M. Lin and K.Y. Lin et al., 2008. Utilization of ground eggshell waste as an adsorbent for the removal of dyes from aqueous solution. Bioresource Technol., 99: 1623-1629.

Yu, H., Q. Tang, J. Wu, Y. Lin and L. Fan et al., 2012. Using eggshell membrane as a separator in supercapacitor. J. Power Sources, 206: 463-468. DOI: 10.1016/j.jpowsour.2012.01.116

Zaki, M.I., H. Knözinger, B. Tesche and G.A.H. Mekhemer, 2006. Influence of phosphonation and phosphation on surface acid-base and morphological properties of $\mathrm{CaO}$ as investigated by in situ FTIR spectroscopy and electron microscopy. J. Colloid Interf. Sci., 303: 9-17. 